\title{
Adenovirus terminal protein mediates both nuclear matrix association and efficient transcription of adenovirus DNA
}

\author{
Jerome Schaack,, ${ }^{1,3}$ William Yew-Wai Ho, ${ }^{1,4}$ Paul Freimuth, ${ }^{2}$ and Thomas Shenk ${ }^{1,5}$ \\ ${ }^{1}$ Howard Hughes Medical Institute, Department of Biology, Princeton University, Princeton, New Jersey 08544 USA; \\ ${ }^{2}$ Laboratory of Cellular Physiology and Immunology, Rockefeller University, New York, New York 10021 USA
}

\begin{abstract}
Adenovirus DNA is tightly bound to the nuclear matrix throughout the course of infection. Analysis of adenovirus DNA from infected HeLa cell nuclei after extraction with lithium diiodosalicylate and digestion with restriction enzymes demonstrated that the sites of tightest attachment occur in the terminal fragments of the linear viral chromosome. Analysis of viruses mutated in the precursor terminal protein coding sequence demonstrated that the terminal protein, which is covalently attached to the $5^{\prime}$ end of each DNA strand, mediates the tight binding. Virions containing chromosomes with mutant terminal proteins were unpackaged and viral DNA accumulated in the nucleus at a normal rate and competed for the limiting component during transcription complex formation, but their early genes were transcribed at reduced efficiency by both RNA polymerases II and III. The transcriptional defects were not complemented by coinfection with a wild-type virus. We propose that the adenovirus chromosome may exist as a single chromatin domain during infection and that binding of DNA to the nuclear matrix may play a critical role in adenovirus transcription.
\end{abstract}

[Key Words: Adenovirus terminal protein; nuclear matrix; adenovirus transcription]

Received February 6, 1990; revised version accepted April 25, 1990.

DNA is organized into domains within eukaryotic chromosomes. Domains are thought to correspond to DNA loops, ranging in size from 5 to $200 \mathrm{~kb}$, that are anchored at their bases to the nuclear matrix (for review, see Feinberg and Coffey 1982; Pienta and Coffey 1984). Attachment of specific DNA sequences to the nuclear matrix has been suggested to play critical roles in DNA replication and gene expression. Attachment may lead to activation or inactivation of entire domains of DNA containing many genes. It may also help to increase local concentration of factors involved in transcription and replication (e.g., Nelson et al. 1986).

The notion that the nuclear matrix exists as a discrete structure has been a subject of controversy (for review, see Cook 1988). Experimentally prepared "nuclear matrix" consists of the proteinaceous nuclear cage plus the RNA that remains after nuclei are extracted by one of several procedures. The original method of extraction involved the use of buffer containing a high salt concentration (Berezney and Coffey 1974). More recently, other protocols have been detailed that involve low salt concentration plus the detergent lithium diiodosalicylate (LIS) (Mirkovitch et al. 1984), intermediate salt concen-

Present addresses: ${ }^{3}$ Department of Microbiology and Immunology, University of Colorado Health Sciences Center, Denver, Colorado 80262 USA; ${ }^{4}$ Department of Microbiology and Immunology, Stanford University School of Medicine, Stanford, California 94305 USA.

${ }^{5}$ Corresponding author. tration (Fey et al. 1986), or physiological salt concentration after encapsulation of the nuclei in agarose (Jackson and Cook 1985). Some of these current technical advances in sample preparation have permitted the visualization of the nuclear matrix in a reproducible manner (Fey et al. 1986).

Regions of specific attachment of DNA to the nuclear matrix [matrix attachment regions (MARs)] have been shown to comap with the boundaries of a chromatin domain for a chicken lysozyme gene (Phi-Van and Strätling 1988). MARs have been mapped to the $5^{\prime}$-flanking regions of active genes in Drosophila (Mirkovitch et al. 1984; Small et al. 1985; Gasser and Laemmli 1986a) and Chinese hamster cells (Dijkwel and Hamlin 1988). Intragenic MARs have been mapped in the murine $\kappa$ lightchain gene (Cockerill and Garrard 1986) and in the Chinese hamster dihydrofolate reductase gene (Kas and Chasin 1987). MARs have been found close to enhancer sequences (Gasser and Laemmli 1986a), although the two elements are separable in at least some instances (Cockerill and Garrard 1986). MARs have been mapped near replication initiation sites (Dijkwel and Hamlin 1988), and origin and centromere elements have been shown to bind to the nuclear matrix in yeast (Amati and Gasser 1988). Consensus topoisomerase II binding sites are found within MARs (Cockerill and Garrard 1986; Gasser and Laemmli 1986b; Kas and Chasin 1987), which has led to the suggestion that this enzyme plays a 
role in binding DNA to the nuclear matrix (Cockerill and Garrard 1986; Gasser and Laemmli 1986b).

There is a great deal of indirect evidence supporting a role for the nuclear matrix in replication, transcription, and mRNA processing and transport (for review, see Verheijen et al. 1988). Placement of a chicken lysozyme gene MAR upstream of a reporter gene led to increased expression in a manner independent of position after stable transfection (Stief et al. 1989), supporting the idea that specific association of DNA with the nuclear matrix contributes to transcriptional efficiency. However, it is difficult to evaluate the role of nuclear matrix in eukaryotic gene expression because of technical problems encountered in manipulating MARs, in controlling for the effects of nearby MARs on cellular chromosomes, and in demonstrating a direct effect of these manipulations on transcription.

The nuclear matrix appears to play a central role in the adenovirus (Ad) growth cycle. All of the Ad fragments generated by restriction digestion of infected cell nuclei were shown to remain bound to the nuclear matrix after extraction with buffer containing a high salt concentration (Younghusband and Maundrell 1982). Recently, the terminal fragments of the Ad chromosome have been shown to be preferentially retained in the nuclear matrix fraction during the late phase of the infection (Bodnar et al. 1989). Virion assembly and maturation occur in association with the nuclear matrix (Khitoo et al. 1986; Zhonge et al. 1987), and the ultrastructure of the nuclear matrix is altered during the late phase of the viral growth cycle (Zhonge et al. 1987; Zhai et al. 1988).

We employed the LIS extraction protocol (Mirkovitch et al. 1984) to reexamine the association of the Ad chromosome with the nuclear matrix. The sites of strongest association occurred in the terminal regions of the viral chromosome. The strong association is mediated by the virally encoded $55-\mathrm{kD}$ terminal protein (TP). TP is covalently bound to the $5^{\prime}$ end of each viral DNA strand (Robinson et al. 1973; Rekosh et al. 1977) and is synthesized as a $80-\mathrm{kD}$ precursor (pTP), which acts to prime Ad DNA replication (for review, see Stillman 1983; Kelly 1984|. Mutant viruses carrying alterations within the TP gene exhibited a reduction in the strength of the association between viral DNA and the nuclear matrix. These mutants also displayed reduced levels of transcription by RNA polymerases II and III, raising the possibility that nuclear matrix association may be essential for optimal transcriptional activity of the Ad chromosome.

\section{Results}

\section{Nuclear matrix association of Ad DNA}

To monitor the association of Ad DNA with the nuclear matrix, HeLa cells were harvested at various times after infection with either wild-type virus (d1309) or an E1 A ${ }^{-}$ variant (d1343). Nuclei were prepared, extracted with LIS to yield nuclear matrices, and digested with HindIII to yield large fragments so that the entire viral chromosome could be screened for potential nuclear matrix as- sociation sites. The solubilized and nuclear matrix-associated DNAs were assayed by Southern analysis probing with ${ }^{32}$ P-labeled total Ad DNA (Fig. 1). The terminal DNA fragments were retained in the nuclear matrix fraction at all times after infection. In contrast, the internal fragments were partially solubilized at all times after infection. It was difficult to digest either HeLa or Ad DNA in nuclear matrix preparations to completion with HindIII, particularly when the nuclear matrices were isolated from cells in the early phase of infection (the DNA was not redigested after isolation to avoid biasing the results; redigestion of partial digestion products, which included terminal and internal fragments, would lead to the artifactual appearance of increased nuclear matrix association for the internal fragments). The partial digestion products that contained a terminal fragment were also retained in the nuclear matrix fraction (noted in Fig. 1). Under the conditions employed, Ad DNA replication began at $\sim 4.5 \mathrm{hr}$, and was maximal near $12 \mathrm{hr}$ after infection (data not shown). Thus, nuclear matrix association of Ad DNA did not appear to change with the onset of replication. The terminal DNA fragments from $d 1343$ were also specifically retained in the nuclear matrix fraction prepared $4.5 \mathrm{hr}$ after infection, demonstrating that expression of the E1A transcriptional activator protein was not required for the normal association of Ad DNA fragments. The use of large restriction fragments in this analysis means that there was increased likelihood of "trapping" DNA fragments within the nuclear matrices. Thus, the fraction of the internal fragments specifically associated with the nuclear matrix is probably overestimated in this analysis. Nevertheless, this evidence indicates that there is a strong MAR located within each of the Ad terminal fragments throughout the infection.

To examine more stringently nuclear matrix association of the left end of the Ad chromosome, cleavage with $B s p R I$, which cleaves 14 times within the left terminal 2.8-kb HindIII restriction fragment to yield small DNA fragments, and secondary extraction with $2 \mathrm{M} \mathrm{NaCl}$ (Mirkovitch et al. 1984) were used. Nuclear matrices prepared by LIS extraction were digested with $B s p$ RI before or after secondary extraction with $2 \mathrm{M} \mathrm{NaCl}$. The 269-bp Ad left terminal fragment bound to the nuclear matrix before and after extraction with $2 \mathrm{M} \mathrm{NaCl}$ (Fig. 2). In contrast, extraction with $2 \mathrm{M} \mathrm{NaCl}$ after, but not before, restriction digestion of LIS-extracted Drosophila nuclei led to solubilization of all DNA fragments, including those that associated with the nuclear matrix after LIS extraction alone (Mirkovitch et al. 1984). The internal Ad BspRI restriction fragments were solubilized much more efficiently than were the larger fragments resulting from digestion with HindIII (cf. Fig. 2 with Fig. 1). This provides further evidence that the terminal region of the Ad chromosome contains a strong and specific MAR.

\section{The role of terminal protein in nuclear} matrix association

The terminal regions of the Ad chromosome share two 

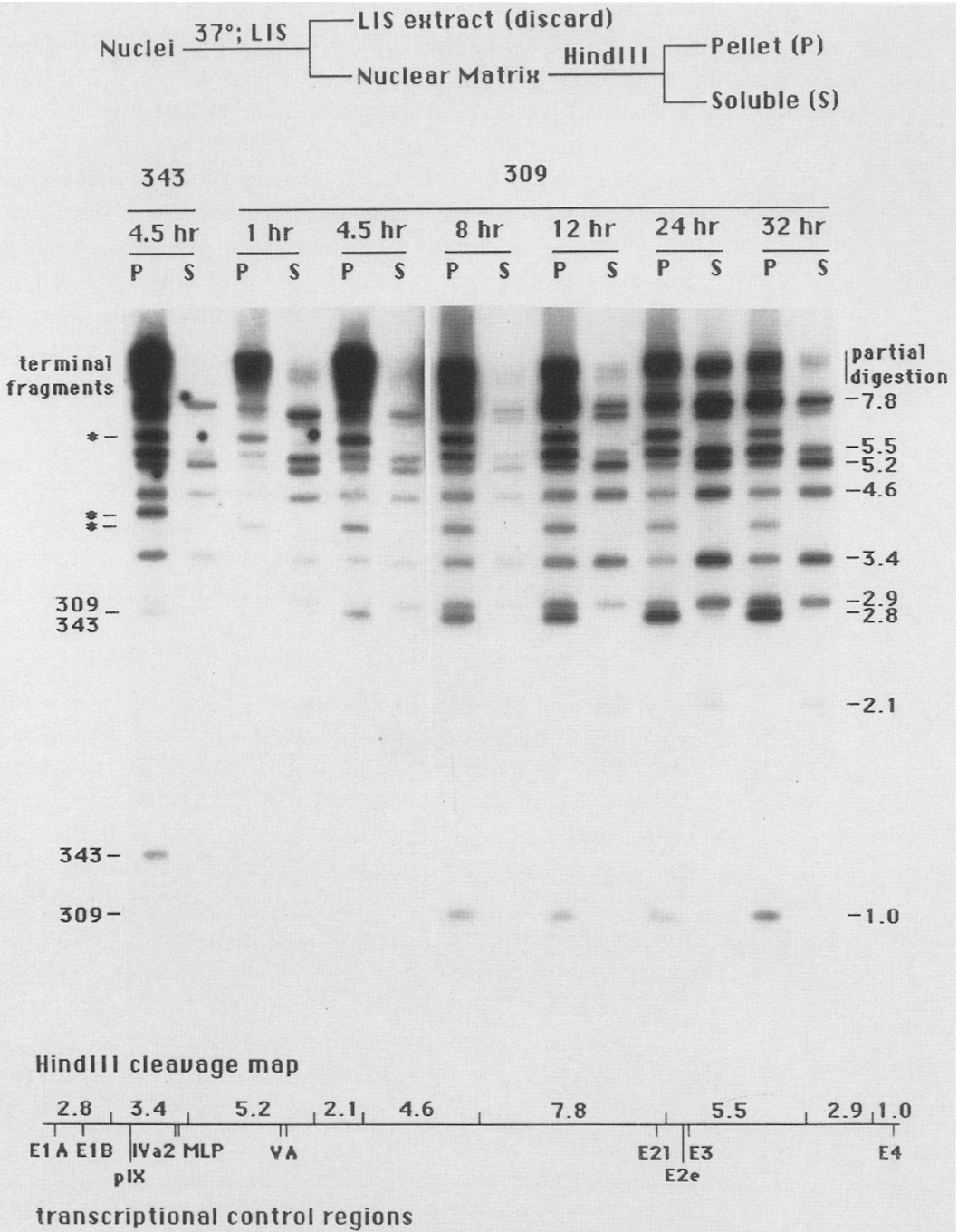

Figure 1. Association of Ad DNA HindIII restriction fragments with the nuclear matrix. HeLa suspension cells were infected with either dl309 (phenotypically wild type) or dl343 $\left(\mathrm{E} \mathrm{A}^{-}\right)$at a multiplicity of $100 \mathrm{PFU} / \mathrm{cell}$. At the times after infection indicated, cells were harvested, nuclei were prepared, extracted with LIS, digested with HindIII, and the solubilized DNA fragments (lanes $S$ ) were separated from the pelleted, nuclear matrix-bound fragments (lanes $P$ ), as indicated in the flow diagram (top). The DNA was deproteinized, and identical amounts of Ad DNA in each lane were resolved by agarose gel electrophoresis, denatured, transferred to nitrocellulose, and probed with uniformly ${ }^{32} \mathrm{P}$-labeled Ad DNA. The terminal DNA fragments $[2.8 \mathrm{~kb}$ and $1.0 \mathrm{~kb}$ for the left and right ends, respectively, of $d 1309 ; 2.8 \mathrm{~kb}$ and 1.3 $\mathrm{kb}$ for $d 1343$, which has the packaging/ElA enhancer regions reiterated at the right end of the chromosome [Hearing and Shenk 1985)] are indicated on the left side of the figure. Partial digestion products that contain the termini are indicated by asterisks. Large partial digestion products, resulting from incomplete digestion of DNA in the nuclear matrix after LIS extraction, occur as a smear near the top of the autoradiograph. Sizes of complete digestion products are indicated in kilobases on the right side of the figure. A map of the Ad genome with HindIII restriction sites and fragment sizes indicated above and transcription control regions indicated below is presented below the autoradiograph. obvious structural features: Inverted terminal repeats of $103 \mathrm{bp}$ and the terminal protein (TP) convalently attached to the 5' end of each DNA strand (Robinson et al. 1974; Rekosh et al. 1977). Either or both of these structures could mediate binding to the nuclear matrix.

A role for TP in nuclear matrix association was explored using viruses with mutations in the terminal protein gene (Fig. 3; Freimuth and Ginsberg 1986). These mutants grow slowly, but eventually produce yields approaching those of wild-type virus (data not shown). To examine the nuclear matrix association of specific domains of cellular DNA, the DNA must be digested with a restriction enzyme to separate the MARs of interest from the many other MARs on the same chromosome. In contrast, Ad DNA appears to contain only two strong MARs. If these correspond to a TP molecule at each end of the chromosome, a TP mutation would simultaneously alter both MARs. As a result of weakened attachment of TP to the nuclear matrix, the Ad chromosome would be released from the nuclear matrix without digestion. Accordingly, $4 \mathrm{hr}$ after infection of HeLa cells with wild-type or mutant viruses (before the onset of DNA replication), nuclei were prepared and extracted with LIS. The resultant nuclear matrices were pelleted, DNA prepared from the pelleted (nuclear matrix) and soluble fractions without restriction digestion and bound to nitrocellulose using a slot blot apparatus, and viral DNA quantified by hybridization with a ${ }^{32} \mathrm{P}-\mathrm{la}$ beled probe consisting of the entire Ad chromosome (Fig. 4, Table 1). This protocol, which avoids restriction digestion and transfer of the DNA from an agarose gel, permits accurate quantitation of the fraction of chromosomes released during LIS extraction. All of the TP mutations examined led to reduced nuclear matrix association. Generally, the amount of Ad DNA retained in the nuclear matrix fraction was reduced by a factor of $5-10$ in the TP mutants compared to the wild-type. In contrast, isolated Ad chromosomes, in which TP was denatured, were incapable of binding to nuclei either before or during extraction with LIS (Fig. 5). This further indicates that the association of the viral chromosome with the nuclear matrix is specific and not a result of aggregation or precipitation in the LIS solution.

Southern analysis of the HindIII-digested nuclear ma- 


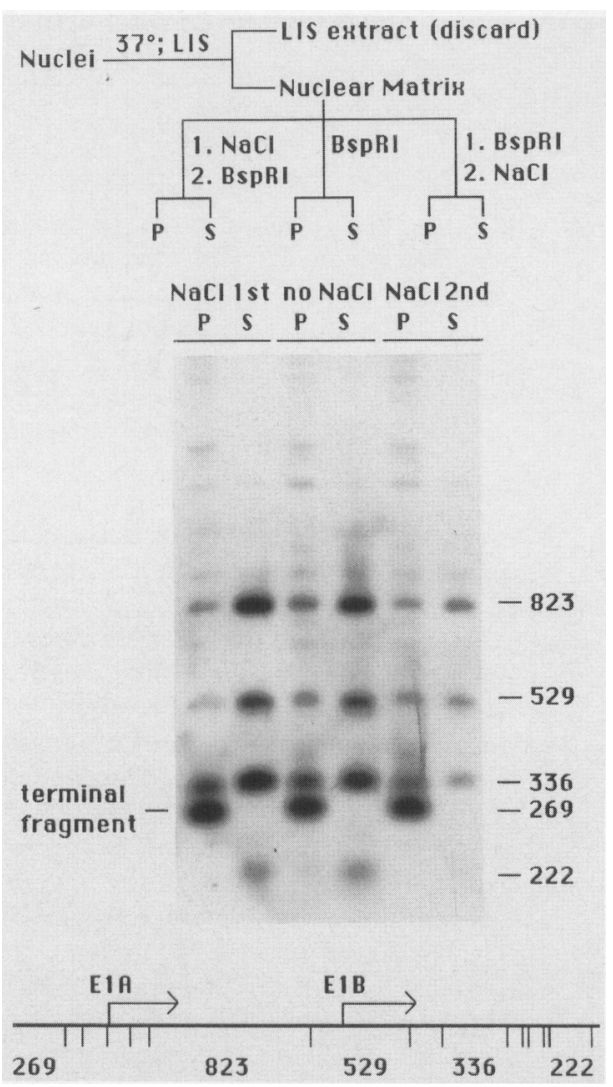

Figure 2. Specificity of binding to the nuclear matrix by the Ad left DNA terminus. HeLa suspension cells were harvested $12 \mathrm{hr}$ after infection with $d 1309$, nuclei were isolated, and nuclear matrices were prepared by LIS extraction. The matrices were either extracted with $2 \mathrm{M} \mathrm{NaCl}$ before (lanes $\mathrm{NaCl} 1 \mathrm{st}$ ) or after (lanes $\mathrm{NaCl}$ 2nd) digestion with BspRI, or digested without extraction with $2 \mathrm{M} \mathrm{NaCl}$ (lanes no $\mathrm{NaCl}$ ), as indicated in the flow diagram (top). The nuclear matrix-associated (lanes $P$ ) and solubilized (lanes $S$ ) DNA fragments were deproteinized, resolved by agarose gel electrophoresis, denatured, transferred to a nylon membrane, and probed with the ${ }^{32} \mathrm{P}$-labeled left terminal HindIII DNA fragment $(2805 \mathrm{bp})$. The lane with DNA solubilized by $2 \mathrm{M} \mathrm{NaCl}$ after digestion with BspRI does not include the DNA solubilized by $B s p$ RI digestion after LIS extraction. The terminal DNA fragment is identified, and the sizes of the completely digested DNA fragments are indicated. A schematic presentation of the left end of the chromosome is presented, with the E1A and E1B transcription start sites indicated above, the locations of $B s p \mathrm{RI}$ cleavage sites indicated by vertical lines below, and the locations of the fragments from the autoradiograph indicated by their sizes below. The terminal fragment runs anomalously slow, possibly due to the presence of a residual fragment of covalently attached protein. The 222 bp fragment is poorly labeled due to the fact that it overlaps only $31 \mathrm{bp}$ of the probe.

trix-associated DNA from cells infected with sub 100 indicated that, of the relatively small amount of viral DNA that was associated with the nuclear matrix, the terminal fragments were preferentially retained (data not shown) as is expected if TP is the site of attachment and the binding constant is reduced by the mutation.

Efficient association of the wild-type chromosome and inefficient association of the TP-mutant chromosomes with the nuclear matrix could be explained by non-specific binding of TP if the mutant TPs were degraded before or during infection. Degradation of mutant TPs before packaging or while in the virion was examined. TP-DNA complexes were purified from wild-type (dI309) and mutant virions, and the proteins ${ }^{125}$ I-labeled. The DNA was then degraded, and the proteins were analyzed by gel electrophoresis (Fig. 6). TP was present at approximately the same molar ratio on wild-type and mutant chromosomes. Western blot analysis of TP from DNA-TP complexes isolated $4 \mathrm{hr}$ after infection demonstrated that TP from the PTP-mutant viruses was not degraded during the early phase of infection (data not shown). Thus, the mutations did not lead to degradation of TP.

During infection by adenovirus, viral DNA reaches the nucleus as part of core particles. The capsid proteins remain outside the nuclear envelope when the core structures enter the nucleus (Morgan et al. 1969; Chardonnet and Dales 1972). This indicates that unpackaging is dependent primarily on the host cell and the outer proteins of the viral capsid. However, TP could contribute to unpackaging. To examine this possibility, the accessibility of the TP-mutant chromosomes in the nucleus was examined through the use of a transcriptioncompetition assay. This assay measures transcription complex formation without disruption of the cells, so potential artifacts are minimized. Preinfection by one adenovirus can lead to inhibition of transcript accumulation from a second, superinfecting adenovirus due to the binding of limiting transcription components by the first virus to infect (J. Schaack, J. Logan, E. Vakalopoulou, and T. Shenk, in prep.). The degree of inhibition is reduced in the presence of high concentrations of the E1A 289R transcriptional activator protein, the limiting

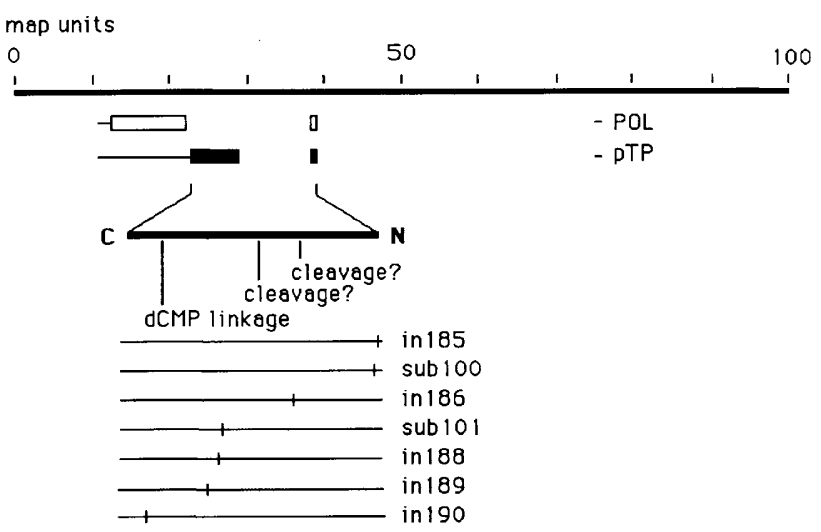

Figure 3. Map of the pTP coding region and location of mutations. The Ad E2B coding region and mRNAs are shown. The solid rectangles indicate the region encoding $\mathrm{PTP}$ and the open rectangles indicate the region encoding Ad DNA polymerase. The sites of in-frame insertions and deletions for pTP mutants (Freimuth and Ginsberg 1986) used in this study are presented below. Two possible sites of cleavage of pTP during the maturation to TP are indicated (Smart and Stillman 1982; Tremblay et al. 1983). 
component in E1A-dependent transcription (Brunet and Berk 1988|, so viral DNAs producing little or no wildtype E1A protein are efficient competitors if they bind transcription factors. Cells were infected with TP mutants (as well as E1A- and wild-type viruses as controls) for $30 \mathrm{~min}$ before superinfection with dl310. dl310 is phenotypically wild type, but contains an in-frame deletion within the region of the ElA gene encoding the $3^{\prime}$ end, and thus produces transcripts that are distinguishable from those of the preinfecting viruses in an RNase protection assay (Winberg and Shenk 1984). Four hours after infection with $d 1310$, RNA was prepared and examined by RNase protection. If the TP-mutant DNAs were not unpackaged within the 30 -min preinfection, the viral promoters would not be capable of binding transcription components, and transcript accumulation from the superinfecting dl310 would not be affected. Alternatively, if the TP-mutant DNAs were unpackaged and were capable of binding the limiting transcription component(s), transcript accumulation from the superinfecting dl310 would be reduced. The TP-mutant viruses competed for the limiting transcription component(s) as efficiently as the $\mathrm{ElA}^{-}$virus $\mathrm{dl343}$ (Fig. 7), demonstrating that their promoters were accessible in the nucleus. The wild-type virus competed to a lesser degree due to efficient production of the ElA transcriptional activator protein.

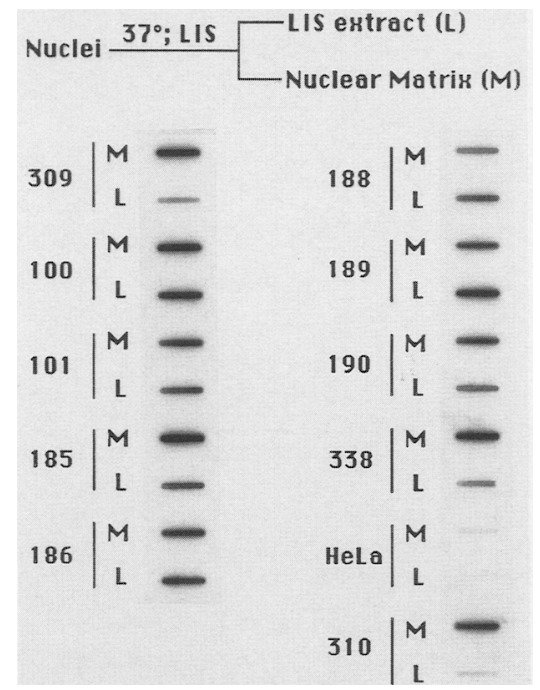

Figure 4. The role of TP in nuclear matrix association of viral DNA. HeLa suspension cells were infected with pTP-mutant viruses (sub100 through in 190) and various control viruses with wild-type terminal proteins $(d 1309, d 1338$, and $d 1310)$ such that the same amount of Ad DNA reached the nuclei. Four hours later (before the onset of DNA replication), cells were harvested and nuclei were prepared and LIS extracted, as indicated in the flow diagram (top). The DNAs released by LIS extraction $(\mathrm{L})$ and retained in the nuclear matrices (M) were purified, denatured, applied to nitrocellulose using a slot blot apparatus $(2 \mu \mathrm{g}$ of total matrix-associated DNA or an equivalent fraction of solubilized DNA per slot), and probed with uniformly ${ }^{32}$ P-labeled Ad DNA. HeLa DNA represents background in the absence of infection. Quantitation of the data is presented in Table 1.
Table 1. Association of pTP-mutant Ad DNA with the nuclear matrix

\begin{tabular}{|c|c|c|c|c|c|}
\hline \multirow{2}{*}{$\frac{\text { Virus }}{d 1309}$} & \multicolumn{4}{|c|}{$\begin{array}{l}\text { Ratio of matrix-bound } \\
\text { DNA to solubilized DNA }\end{array}$} & \multirow{2}{*}{$\begin{array}{l}\begin{array}{l}\text { Normalized } \\
\text { ratio }\end{array} \\
1.0\end{array}$} \\
\hline & 5.4 & 6.9 & 4.8 & 10.2 & \\
\hline$d 1338$ & 5.9 & 5.6 & ND & ND & 0.95 \\
\hline$d 1310$ & 6.5 & 6.7 & ND & ND & 1.1 \\
\hline sublo0 & 0.87 & 1.4 & 1.1 & 1.0 & 0.16 \\
\hline$s u b 101$ & 1.6 & 1.0 & 1.3 & 1.4 & 0.19 \\
\hline in185 & 0.96 & 1.6 & 0.80 & 1.5 & 0.18 \\
\hline in 186 & 0.63 & 1.0 & 1.1 & 2.7 & 0.20 \\
\hline in 188 & 0.89 & 0.56 & 0.97 & 2.2 & 0.17 \\
\hline in 189 & 0.55 & 0.60 & 0.91 & 0.82 & 0.11 \\
\hline in 190 & 1.0 & 1.4 & 0.90 & 2.3 & 0.20 \\
\hline
\end{tabular}

The bands from the slot blot in Fig. 3 as well as blots from three other experiments were cut out, the specific activity quantitated by liquid scintillation counting, and the values expressed as the ratio of nuclear matrix-associated DNA to DNA solubilized by LIS extraction. The ratios were normalized by dividing by the ratio of bound/solubilized DNA for $d 1309$, and are given as averages for all four determinations. dl309, dl338, and dl310 are wild type for pTP, while sublo0 through in 190 carry mutations in this gene. (ND) Not determined.

The accessibility of the dTP mutant chromosomes in the nuclei of infected cells was also examined by limited DNase I digestion at various times from 30 to $60 \mathrm{~min}$ after infection (data not shown). pTP-mutant and wildtype viral chromosomes became susceptible to digestion at the same rate, indicating further that the pTP mutations did not affect unpackaging of the viral chromosome. Thus, both physical and genetic criteria indicated that unpackaging of the TP-mutant chromosomes occurs within the first $30 \mathrm{~min}$ of infection. We conclude that mutations within TP can alter the association of the Ad chromosome with the nuclear matrix.

\section{Transcriptional control exerted through terminal protein}

The test of the ability of TP mutant viruses to compete for the limiting transcription component|s| indicated

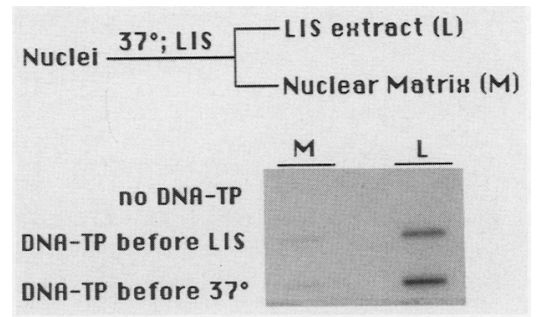

Figure 5. Ad chromosomes with denatured TP do not bind to the nuclear matrix in vitro. d1309-TP complexes were isolated after denaturation of virion proteins. Purified complexes were added to isolated HeLa cell nuclei either before treatment of the nuclei at $37^{\circ} \mathrm{C}$ or immediately before extraction with LIS, as indicated in the flow diagram (top). The DNAs released by LIS extraction (L) and retained in the nuclear matrices (M) were purified and probed as in Fig. 4. 


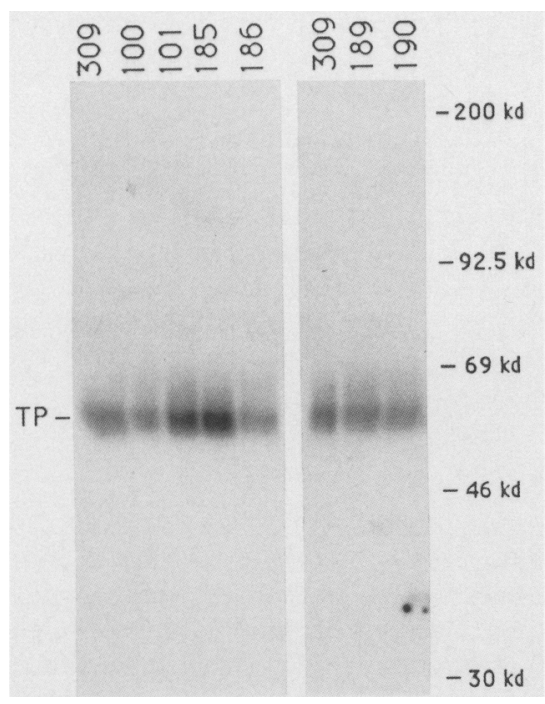

Figure 6. The state of TP in pTP-mutant virions. TP-DNA complexes were purified and ${ }^{125}$ I-labeled using Bolton-Hunter reagent; DNA was degraded by incubation with pyridine; and TP was resolved by SDS-DEAE. Sizes of protein standards are indicated in kilodaltons.

that the TP mutations led to reduced transcription (Fig. 7). To test further the correlation between reduction in nuclear matrix association of Ad DNA and transcription of Ad genes, cytoplasmic and nuclear ElA mRNA accumulation from singly infected cells was examined (Fig. $8 \mathrm{~A}, \mathrm{~B})$. In the construction of the TP-mutant viruses, a frameshift mutation was introduced into a HindIII site in the E1B 55-kD coding region (Freimuth and Ginsberg 1986), which, by comparison with other E1B 55-kD mutant viruses (Williams et al. 1986; Pilder et al. 1986), could lead to defects in mRNA metabolism late, but not early, in the infectious cycle. A variant that expresses wild-type TP, but which has a deletion of a restriction fragment beginning at the same HindIII site within the ElB coding region (dl338; Logan et al. 1984), was used for comparison with the TP mutants. RNAs from a phenotypically wild-type virus $(\mathrm{d} 1309)$ and an $\mathrm{ElA}^{-}$virus (d1343) were also analyzed as controls. For all of the TP mutants, E1A mRNA levels were substantially reduced relative to those of $d 1338$, which was equivalent to the wild-type dl309. The relative concentration of E1A mRNAs was similar in both the nucleus and cytoplasm, suggesting that there was not a defect in mRNA transport early in the infectious cycle.

The ElA gene encodes a protein that transcriptionally activates all of the early region Ad genes, including the E1A gene itself (Berk et al. 1979; Jones and Shenk 1979a; Hearing and Shenk 1985). Because expression of ElA mRNAs was reduced in the TP mutants, the concentration of the E1A transcriptional activator protein was also reduced. To examine the extent of the transcriptional defect in the TP mutants as well as to ask whether E1A proteins can act to overcome the defect in nuclear matrix association, E1A proteins were added in trans by coinfection with $d 1310$ (Fig. $8 \mathrm{C}$ ). The presence of wild-type E1A proteins strongly activated transcription from an E1A- virus (d1343), but had little effect on cytoplasmic RNA accumulation from the pTP-mutant viruses /cf. intensities of the bands corresponding to the

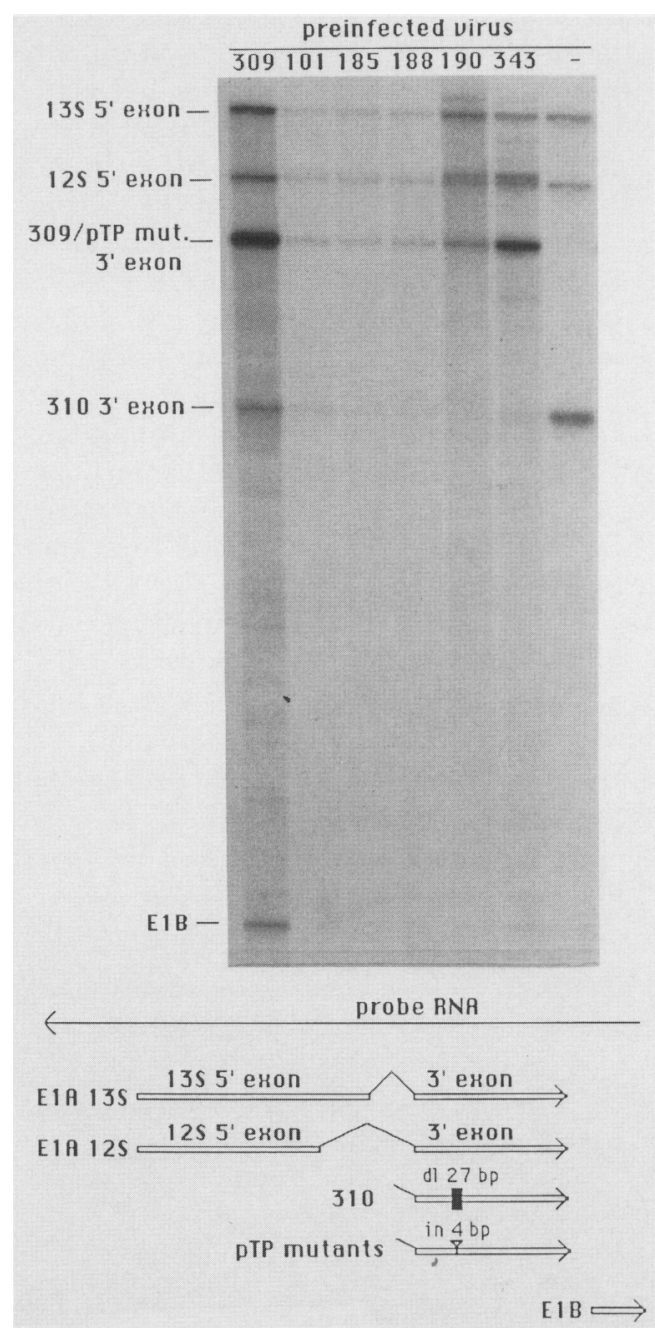

Figure 7. Binding of limiting transcription components by pTP-mutant DNAs. HeLa cells were mock-infected or infected with pTP-mutant viruses, wild-type virus $(d \mathrm{l} 309)$, or an E1Avirus (dl343) such that the same amount of Ad DNA reached the nuclei. After $30 \mathrm{~min}$, the cells were superinfected with dl310. Four hours after infection with $d 1310$, the cells were harvested, and cytoplasmic RNA was prepared. The RNA samples were examined for ElA mRNA by RNase protection (Melton et al. 1984). The protected fragments were resolved by polyacrylamide gel electrophoresis. Protected fragments from both wildtype and PTP-mutant viruses are identified. A schematic presentation of the El region and the E1-specific probes is presented below. Open rectangles indicate regions protected by the ElA and E1B mRNAs. dl310 has a 27-bp deletion denoted by a solid rectangle that leads to the production of two small 3 ' exon fragments / the smaller protection fragment is not included on the autoradiograph). The pTP-mutant viruses have a 4-bp insertion, which leads to variable cleavage of the probe RNA within the $3^{\prime}$ exon (see Fig. 8). The ability of the preinfected viruses to compete for the limiting transcription component is indicated by the degree of reduction in concentration of dl310-specific E1A mRNA. 


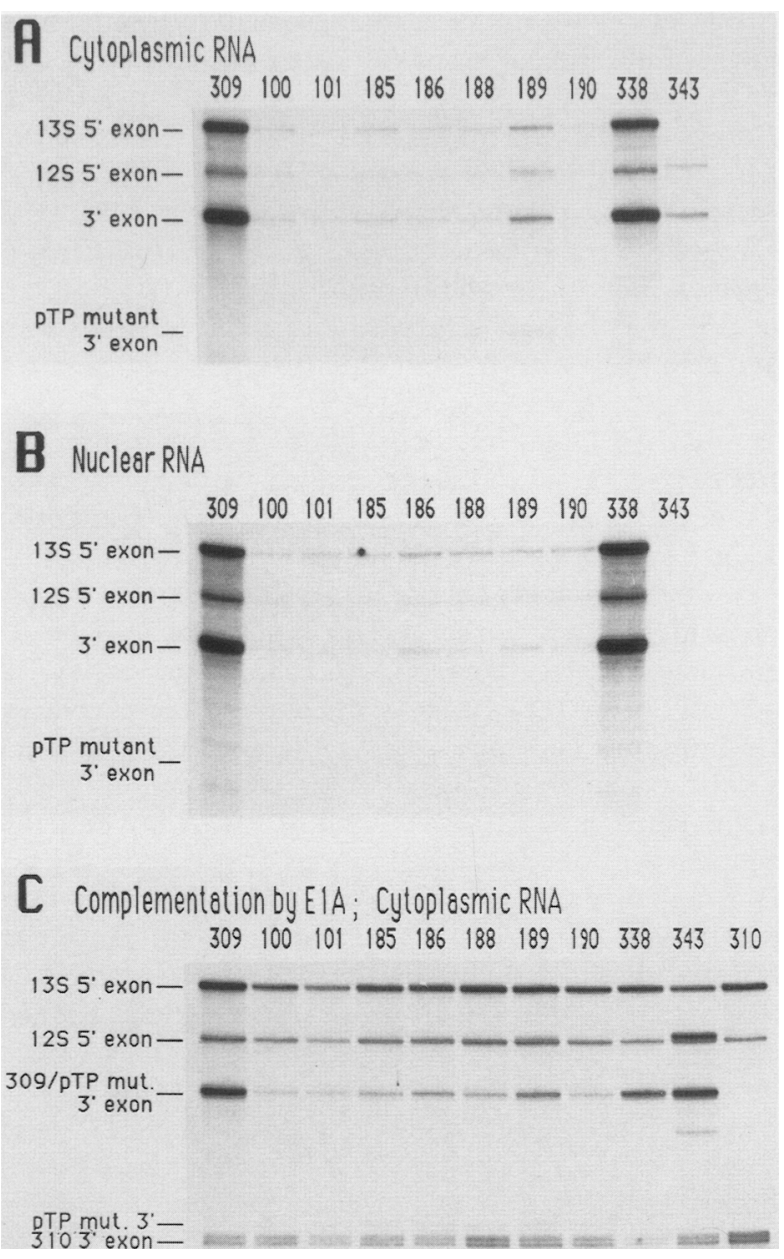

Figure 8. E1A transcription from pTP-mutant viruses. HeLa cells were either singly infected such that the same amount of Ad DNA reached the nuclei or coinfected with dl310. Four hours later, the cells were harvested, and RNA /cytoplasmic and nuclear) prepared. The RNA samples were examined for E1A mRNA by RNase protection. The protected fragments were resolved by polyacrylamide gel electrophoresis. Protected fragments from both wild-type and pTP-mutant viruses are identified. (A) Cytoplasmic RNA from singly infected cells. (B) Nuclear RNA from singly infected cells. $(C)$ Cytoplasmic RNA from coinfected cells to assay complementation by E1A.

$3^{\prime}$ exon in Fig. 8C to those in Fig. 8A). Thus, the TP mutations led to a cis-acting defect in transcription.

The E1A promoter is located within the first $500 \mathrm{bp}$ of the left end of the virus, and thus close to a MAR. If the Ad chromosome is organized as a single DNA domain between terminal MARs, a transcriptional defect should also be observed for genes whose promoters are located at a distance from a viral chromosomal terminus. To examine whether this was the case, RNA accumulation from the E2A region was examined (the E2A early promoter is located at 75 map units, or $9 \mathrm{~kb}$ from the nearer MAR|. Because E2A transcription is very responsive to E1A proteins, E1A proteins were supplied in trans by infecting 293 cells, which contain and express the E1 genes from Ad5 (Graham et al. 1977). E2A RNA accu- mulation was also reduced for the TP mutants relative to the wild-type virus (Fig. 9A). In control experiments, the levels of ElA proteins and mRNAs were found to be the same for uninfected 293 cells and for 293 cells infected with TP-mutant or wild-type viruses (data not shown). Nuclear matrix association of the TP-mutant chromosomes in 293 cells was found to be defective to a similar degree as in HeLa cells (data not shown). Thus, it appears that transcription of Ad genes by RNA polymerase II and nuclear matrix association of Ad DNA are both dependent on a functional TP.

The Ad chromosome contains two genes, the VAI and VAII RNA genes, which are transcribed by RNA polymerase III. RNA accumulation from these genes is also dependent on E1A proteins (Hoeffler and Roeder 1985; Yoshinaga et al. 1986). VA RNA accumulation was examined by use of RNA isolated from the same infected 293 cells as for E2A mRNA analysis. Accumulation of VA RNAs was reduced from the TP mutants relative to the wild-type virus (Fig. 9B). Thus, efficient RNA polymerase III-directed transcription also correlated with nuclear matrix association.

The experiments presented above suggest strongly that the primary defect in RNA accumulation from the TP mutants lies at the level of transcription. To confirm this, transcription run-on assays using isolated nuclei from 293 cells infected with either $d 1338$ (with wild-type TP) or in 188 (with mutant TP) were performed (Table 2). Because of the high level of expression of the endogenous E1A gene in 293 cells, no difference between the

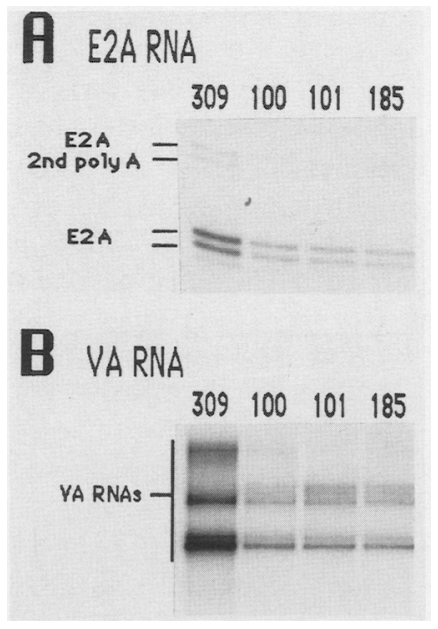

Figure 9. E2A and VA RNA transcription from pTP-mutant viruses. 293 cells were infected such that the same amount of Ad DNA reached the nuclei. Four and one-half hours after infection, cells were harvested, and total RNA prepared. The RNA samples were examined for E2A mRNA (panel A) or VAI and VAII RNA (panel B) by RNase protection. Protected species are indicated. The longer E2A species results from the use of a second polyadenylation site. Transcription initiation for the VAI RNA gene occurs from two sites when the 5 '-flanking sequence is wild-type (as for the pTP-mutant viruses), but only from the second site when the nearby $X b a I$ site has been lost, as in dl309 and dl338 (Thimappaya et al. 1979). 
Table 2. Quantitation of transcription run-on data from 293 cells

\begin{tabular}{lccc}
\hline $\begin{array}{l}\text { Transcription } \\
\text { unit }\end{array}$ & $\begin{array}{l}\text { dl338 sp. act. } \\
(\mathrm{cpm})\end{array}$ & $\begin{array}{l}\text { in188 sp. act. } \\
(\mathrm{cpm})\end{array}$ & Ratio \\
\hline E1A & 367 & 411 & 1.1 \\
E2A & 102 & 32 & 0.31 \\
E4 & 144 & 45 & 0.31 \\
\hline
\end{tabular}

The 293 cells were infected with $d 1338$ or in 188 . Four and onehalf hours after infection (before the onset of replication), nuclei were isolated and pulse-labeled during elongation of nascent transcripts. The RNA was purified and hybridized to specific DNAs immobilized on nitrocellulose using a slot blot apparatus. The bands derived from two independent experiments were cut out, the radioactivity quantified by liquid scintillation counting, the background $(28 \mathrm{cpm})$ subtracted, and the average values presented in $\mathrm{cpm}$ and as a ratio of in $188 / \mathrm{dl} 338$ infected cells. ElA transcription includes transcription from the host cell copy of the ElA gene.

two viruses was observed for ElA transcription rates. Incorporation of label into nascent transcripts from the other early regions examined was reduced in the TP mutant relative to $d 1338$, as expected. Thus, the defect in RNA accumulation is due, at least in part, to a decrease in the rate of transcription.

\section{Discussion}

We draw two main conclusions from this work. First, Ad DNA is bound tightly and specifically to the nuclear matrix through the covalently attached TP (Figs. 1, 2, and 4, Table 1). Second, tight binding is correlated with efficient transcription (Figs. 8 and 9, Table 2). Transcriptional activation by ElA proteins appeared to require efficient nuclear matrix association of the DNA, and E1A proteins supplied in trans did not overcome the defect due to reduced nuclear matrix association (Fig. 8C). Although we have not demonstrated directly that nuclear matrix association is required for Ad transcription, this seems likely, particularly because seven viruses carrying independent mutations in the pTP gene (Fig. 3) all exhibited defects in both nuclear matrix association and transcription.

TP may substitute for the cellular protein or proteins that normally mediate association of MARs with the nuclear matrix. The utilization of the same viral polypeptide to prime replication (for review, see Stillman 1983; Kelly 1984) and bind to the nuclear matrix (Figs. 1, 2 , and 4, Table 1) enables a nascent viral chromosome to become nuclear matrix associated at the moment that its replication begins. These two roles of the TP are functionally related, given the assumption that efficient replication of Ad DNA requires matrix association as is thought to be the case for cellular DNA replication (for review, see Verheijen et al. 1988).

\section{Binding of Ad DNA to the nuclear matrix}

The association of Ad DNA fragments with the nuclear matrix was examined previously by extraction of nuclei with buffer containing a high salt concentration. One of these studies indicated that all Ad DNA restriction fragments are bound throughout the infectious cycle (Younghusband and Maundrell 1982). In contrast, LIS extraction followed by HindIII (Fig. 1) or BspRI (Fig. 2) digestion led to solubilization of internal fragments, whereas the terminal fragments remained almost quantitatively bound. Attachment sites that survive LIS extraction may be bound more tightly than those that are extracted only with buffer containing a high concentration of salt. However, preferential association of small terminal Ad DNA fragments with the nuclear matrix after extraction with buffer containing a high concentration of salt was noted during the late phase of infection (Bodnar et al. 1989).

Promoter regions or activation of transcription did not appear to play a key role in tight binding of Ad DNA to the nuclear matrix. The $\mathrm{pIX}$ and IVa2 promoters are active only after the onset of replication, and the major late promoter becomes much more active at this time (for review, see Flint 1986). These promoters all reside on the same internal 3.4-kb HindIII fragment, but this fragment was not associated more strongly with the nuclear matrix after replication began (Fig. 1). Further, internal DNA fragments that do not contain promoters were not distinguishable by nuclear matrix association from those that do. This does not rule out the possibility that transcriptional control regions or transcription complexes contribute to binding to the nuclear matrix, however. These interactions may not be strong enough to survive LIS extraction. It is possible that weaker binding sites occur at many places on the Ad chromosome, and they may all contribute to the overall strength of nuclear matrix association.

It has been suggested that topoisomerase II may play a critical role in the specific binding of DNA fragments to the nuclear matrix (Gasser and Laemmli 1986b; Cockerill and Garrard 1986). Topoisomerase II has been detected at sites of DNA loop attachment to chromosome scaffolds (Berrios et al. 1985; Earnshaw and Heck 1985; Earnshaw et al. 1985; Gasser et al. 1986). Topoisomerase II, however, does not appear to be sufficient for association of the Ad chromosome with the nuclear matrix. During the early phase of infection, there is very little interaction, and during the late phase, significantly greater interaction, of topoisomerase II with the Ad chromosome. Strong topoisomerase II cleavage sites were observed throughout the viral chromosome, not just in the terminal fragments, during the late phase (Schaack et al. 1990). This contrasts with the specific nuclear matrix association of the terminal fragments and the lack of change in nuclear matrix association of internal fragments of the Ad chromosome during the infectious cycle.

\section{Transcriptional activation by terminal protein}

Transcription of viral genes by both RNA polymerase II and III was inhibited by a variety of mutations in the pTP gene (Figs. 8 and 9, Table 2). TP functioned in cis 
(Fig. 8C) to enhance transcription at a distance. It influenced the activity of the E2 promoter (Table 2) which is $\sim 9 \mathrm{~kb}$ from the nearer TP attachment site. Its ability to act at a distance makes its function appear analogous to that of a transcriptional enhancer.

How does TP influence the efficiency of Ad transcription? It is possible that it acts in a manner similar to cellular DNA-binding proteins that stimulate transcription (for review, see Mitchell and Tjian 1989). In fact, TP contains several sequence characteristics in common with known activation domains of cellular transcription factors. TP contains domains (amino acids 198-247, 13 of 50 acidic residues; amino acids 398-470, 26 of 73 acidic residues; amino acids $549-609,15$ of 53 acidic residues) whose negative charge is comparable to the acidic activating domains in transcription factors such as GCN4 (Hope and Struhl 1986) and GAL4 (Ma and Ptashne 1987). The known acidic activating domains appear to have the capacity to form an amphipathic $\alpha$-helical structure, and computer analysis indicates that two of the three acidic domains in TP exhibit this characteristic. TP also contains two proline-rich domains (amino acids 334-397, 13 of 64 proline residues; amino acids $649-667,10$ of 19 proline residues/ comparable to the proline-rich activating domain of CTF/NF-1 (19 of 84 proline residues, Mermod et al. 1989). It seems unlikely however, that TP, which is not bound to the terminal of the viral chromosome, acts in a fashion similar to the E1A proteins to stimulate a diverse array of transcriptional responses because the transcriptional defect of TP mutants could not be complemented in trans (Fig. 8C). Further, pTP did not act in trans to increase transcription of a reporter gene driven by the E2 early promoter either in the presence or absence of E1A protein as assayed by use of transient cotransfection of the various genes into HeLa cells (C.-Y. Chen and J. Schaack, unpubl.).

TP may also enhance transcription through its ability to mediate attachment of the Ad chromosome to the nuclear matrix. We believe this hypothesis has merit for two reasons. First, seven different mutations spread across the pTP gene (Fig. 3) failed to separate attachment from transcription phenotypes. All seven mutant viruses were defective for nuclear matrix association (Fig. 4, Table 1), and all seven exhibited reduced transcription of viral genes (Figs. 8 and 9, Table 2). Second, an effect of nuclear matrix association on transcription may explain the diversity of genes influenced by the TP mutations. The association could localize the viral chromosome so it has better access to transcription factors within the nucleus (for discussion, see Nelson et al. 1986). Alternatively, terminal matrix attachment sites could organize the viral chromosome into a single domain, and global influences such as torsional stress may modulate expression of all viral genes (for review, see Pienta and Coffey 1984).

We cannot rule out the possibility that TP exerts its transcriptional effects simply by mediating circularization of the viral chromosome (Robinson et al. 1973), but this mechanism seems unlikely. Denaturation of TP does not prevent, and in fact may be required for, its ability to aggregate and generate circular DNA molecules (Robinson et al. 1973). In contrast, denatured TP did not bind detectably to the nuclear matrix in the LIS extraction protocol (Fig. 5), and, given the assumption that the mutations in the TP gene we analyzed disrupt TP structure (discussed below), denatured TP would be unlikely to perform its transcriptional role.

\section{Implications for terminal protein structure}

All of the mutations studied, regardless of location within the PTP coding region, led to a reduced ability of the mutant DNAs to bind to the nuclear matrix (Fig. 4). No correlation could be drawn between the site of the mutation in the TP gene and the degree of the effect on either transcription or binding to the nuclear matrix. It is unlikely that all of the mutations examined directly affect the nuclear matrix binding site. This suggests that the structure of TP is easily perturbed, and that a native structure is required for tight binding.

Mutations near the amino terminus of the pTP coding region block its activity in in vitro replication systems (Pettit et al. 1988) and affect pTP function in vivo (Freimuth and Ginsberg 1986). During maturation of virions, pTP is proteolyzed and the carboxy-terminal $55-\mathrm{kD}$ TP remains covalently attached to Ad DNA (Stillman et al. 1981). The fate of the amino-terminal fragment is not clear. The reduced nuclear matrix association of viral DNAs with mutations in the amino-terminal portion of pTP (Fig. 3) suggests that the amino-terminal fragment may remain associated with the carboxy-terminal $55-\mathrm{kD}$ fragment in the mature virion and after infection, and may contain the actual site of binding to the nuclear matrix. Alternatively, these mutations could exert their phenotype through partial denaturation of the $55-\mathrm{kD}$ TP portion of $\mathrm{pTP}$.

\section{Materials and methods}

\section{Cells and viruses}

Viruses used in these studies were dl309 (phenotypically wild type; Jones and Shenk 1979b), dl338 (E1B $55 \mathrm{kD}^{-}$; Logan et al. 1984), dl343 (E1A - due to a 2-bp deletion near the amino terminus of the coding region; Hearing and Shenk 1985), dl310 (phenotypically wild type with an in-frame deletion of $27 \mathrm{bp}$ in the region encoding the ElA $3^{\prime}$ exon; Jones and Shenk 1979b; Winberg and Shenk 1984), and a series of viruses, indicated in Figure 3, mutated in the pTP coding region (Freimuth and Ginsberg 1986). Viruses were grown from low multiplicity infections (2-3 viral genomes per nucleus, on average) of 293 cells (Graham et al. 1977). The important consideration in these studies was the number of viral genomes reaching the nucleus, so viral stocks were titrated in the following manner: HeLa suspension cells were infected, harvested by pelleting $4 \mathrm{hr}$ later, lysed in SDS, deproteinized by digestion with $100 \mu \mathrm{g}$ of proteinase $\mathrm{K}$ per milliliter overnight at $37^{\circ} \mathrm{C}$ followed by phenol extraction and ethanol precipitation, and digested with RNase $A$; the DNA was denaturated, bound to nitrocellulose using a slot blot apparatus, and probed with uniformly ${ }^{32} \mathrm{P}$-labeled Ad DNA (Feinberg and Vogelstein 1983). The blot was subjected to 
autoradiography, the bands excised from the filter, and the sp. act. determined by liquid scintillation counting. Infections were performed so that an average of 25 viral genomes of each virus used reached each nucleus except where noted. For complementation assays using coinfection, cells were infected at $38^{\circ} \mathrm{C}$ to permit maximal transcription from the complementing virus (J. Schaack, J. Logan, E. Vakalopoulou, and T. Shenk, in prep.). Zero time for infections is the time of mixing of cells and viruses. Most of the analyses were performed using HeLa suspension cells. In certain experiments, 293 cells were used to provide E1A proteins in trans.

\section{Nuclear matrix association assays}

Nuclear matrix association of viral DNA was assayed using the LIS extraction protocol (Mirkovitch et al. 1984) with minor modifications. In brief, nuclei were prepared by lysis of cells in hypotonic buffer [10 $\mathrm{mM}$ Tris- $\mathrm{HCl}(\mathrm{pH} 8), 10 \mathrm{mM} \mathrm{NaCl}$, and 3 $\mathrm{mM} \mathrm{MgCl}_{2}$ ] containing $0.5 \% \mathrm{NP} 40$ followed by washing in isolation buffer $[3.75 \mathrm{mM}$ Tris- $\mathrm{HCl}(\mathrm{pH} 7.4), 0.05 \mathrm{~mm}$ spermine, $0.125 \mathrm{~mm}$ spermidine, $0.5 \mathrm{~mm}$ EDTA, $1 \%$ (vol/vol) thiodyglycol, and $20 \mathrm{~mm} \mathrm{KCl}$ (Mirkovitch et al. 1984)]. Nuclei were resuspended in a minimal volume of isolation buffer lacking EDTA, incubated at $37^{\circ} \mathrm{C}$ for $20 \mathrm{~min}$, and 20 volumes LIS extraction buffer $[5 \mathrm{mM}$ HEPES/NaOH $(\mathrm{pH} 7.4), 0.25 \mathrm{mM}$ spermidine, $2 \mathrm{mM}$ EDTA, $2 \mathrm{mM} \mathrm{KCl}$, and $25 \mathrm{~mm} \mathrm{Li} \mathrm{3,5-diiodosalicy-}$ late (Mirkovitch et al. 1984)] was added slowly with gentle mixing. After $5 \mathrm{~min}$ at room temperature, the nuclei were pelleted, and the supernatant was designated LIS extractable (nonnuclear matrix associated). After four washes with digestion buffer $[20 \mathrm{mM}$ Tris- $\mathrm{HCl}(\mathrm{pH}$ 8), $0.05 \mathrm{mM}$ spermine, $0.125 \mathrm{~mm}$ spermidine, $20 \mathrm{mM} \mathrm{KCl}, 70 \mathrm{mM} \mathrm{NaCl}$, and $10 \mathrm{mM} \mathrm{MgCl} 2$ l, the pelleted material was designated the nuclear matrix fraction. To determine the locations of nuclear matrix attachment sites, DNA from nuclear matrix fractions was digested with HindIII or BspRI and Southern analysis performed with uniformly ${ }^{32} \mathrm{p}$. labeled total Ad DNA or the left terminal HindIII restriction fragment $(1-2805 \mathrm{bp})$ as probe, respectively. To determine the effects of pTP mutations on nuclear matrix association of Ad DNA, the DNA solubilized by LIS extraction of infected nuclei was compared to nuclear matrix-associated DNA by slot blotting and probing as above.

\section{Assays of RNA}

Cytoplasmic RNA was isolated by lysing of cells in hypotonic buffer containing $0.5 \%$ NP40 and deproteinization by digestion with $200 \mu \mathrm{g}$ of proteinase $\mathrm{K}$ per milliliter for $15 \mathrm{~min}$ followed by phenol extraction and ethanol precipitation. Nuclear RNA was prepared by washing of the nuclei in hypotonic buffer containing $0.5 \%$ NP40 and extraction by use of guanidinium thiocyanate and acidified phenol/chloroform (Chomczynski and Sacchi 1987). Total cellular RNA was prepared by extraction with acidified phenol/chloroform in the presence of guanidinium thiocyanate. Specific mRNA concentrations were determined by RNase protection with antisense transcripts synthesized by T7 RNA polymerase in the presence of $\left[\alpha^{-32} \mathrm{P} \mid \mathrm{UTP}\right.$ (Melton et al. 1984). The E1A probe overlaps all of E1A and the first 139 bases of the E1B transcripts. The probe for E2A overlaps the 3'-most 90 bases of the major processed product. The VAI and VAII RNA probe overlaps both VA RNA genes.

Transcription run-on assays (Hofer and Darnell 1981; Groudine et al. 1981) with nuclei isolated from 293 cells $5 \mathrm{hr}$ after infection were performed in the presence of $\left[\alpha^{-32} P\right] U T P$. Labeled RNA was purified by extraction with acidified phenol/chloroform in the presence of guanidinium thiocyanate /Chomc- zynski and Sacchi 1987). The RNA was hybridized to denatured double-strand DNA fragments immobilized on nitrocellulose by use of a slot blot apparatus (McKnight and Palmiter 1979). The blots were subjected to autoradiography, the bands excised from the filter, and the specific activity determined by liquid scintillation counting.

\section{Labeling of TP}

TP-DNA complexes were purified from virions banded twice in $\mathrm{CsCl}$ gradients by sieve chromatography on Sepharose 4B-CL after lysis in SDS plus 2-mercaptoethanol (Challberg and Kelley 1981). The complexes were then ${ }^{125}$ I-labeled by incubation with Bolton-Hunter reagent on ice for $2 \mathrm{hr}$ in $0.1 \mathrm{M} \mathrm{NaB}_{4} \mathrm{O}_{7}$ (pH 9.0), and repurified; the DNA was degraded by incubation in $1 \mathrm{M}$ pyridine for $2 \mathrm{hr}$ at $37^{\circ} \mathrm{C}$, and TP was resolved by SDS-PAGE.

\section{Acknowledgments}

We thank P. Schedl, J. Spencer, and R. Kubo for helpful discussions and advice, E. Vakalopoulou, D. Ornelles, S. Baim, and J. Wilusz for critical reading of the manuscript, E. Vakalopoulou for help and advice in the preparation of figures, and $K$. McNally and A.L. Taylor for computer assistance. This work was supported by a Public Health Service grant from the National Cancer Institute (CA 41086). J. Schaack was a postdoctoral fellow of the Jane Coffin Childs Memorial Fund for Medical Research, and T. Shenk is an American Cancer Society Professor.

The publication costs of this article were defrayed in part by payment of page charges. This article must therefore be hereby marked "advertisement" in accordance with 18 USC section 1734 solely to indicate this fact.

\section{References}

Amati, B.B. and S.M. Gasser. 1988. Chromosomal ARS and CEN elements bind specifically to the yeast nuclear scaffold. Cell 54: 967-978.

Berezney, B. and D.S. Coffey. 1974. Identification of a nuclear protein matrix. Biochem. Biophys. Res. Commun. 60: $1410-1417$

Berk, A.J., F. Lee, T.F. Harrison, J.F. Williams, and P.A. Sharp. 1979. Pre-early adenovirus 5 gene product regulates synthesis of early viral messenger RNAs. Cell 17: 935-944.

Berrios, M., N. Osheroff, and P.A. Fisher. 1985. In situ localization of DNA topoisomerase II, a major polypeptide component of the Drosophila nuclear matrix fraction. Proc. Natl. Acad. Sci. 82: 4142-4146.

Bodnar, J.W., P.I. Hanson, M. Polvino-Bodnar, W. Zempsky, and D.C. Ward. 1989. The terminal regions of adenovirus and minute virus of mice DNAs are preferentially associated with the nuclear matrix in infected cells. J. Virol. 63: 43444353.

Brunet, L.J. and A.J. Berk. 1988. Concentration dependence of transcriptional transactivation in inducible ElA-containing human cells. Mol. Cell. Biol. 8: 4799-4807.

Challberg, M.D. and T.J. Kelly, Jr. 1981. Processing of the adenovirus terminal protein. J. Virol. 38: 272-277.

Chardonnet, Y. and S. Dales. 1972. Early events in the interaction of adenoviruses with HeLa cells. III. Relationship between an ATPase activity in nuclear envelopes and transfer of core material: A hypothesis. Virol. 48: 342-350.

Chomczynski, P. and N. Sacchi. 1987. Single-step method of RNA isolation by acid guanidinium thiocyanate-phenolchloroform extraction. Anal. Biochem. 162: 156-159. 
Cockerill, P.N. and W.T. Garrard. 1986. Chromosomal loop anchorage of the kappa immunoglobulin gene occurs next to the enhancer in a region containing topoisomerase II sites. Cell 44: 273-282.

Cook, P.R. 1988. The nucleoskeleton: Artefact, passive framework or active site? /. Cell Sci. 90: 1-6.

Dijkwel, P.A. and J.L. Hamlin. 1988. Matrix attachment regions are positioned near replication initiation sites, genes, and an interamplicon junction in the amplified dihydrofolate reductase domain of Chinese hamster ovary cells. Mol. Cell. Biol. 8: $5398-5409$.

Earnshaw, W.C. and M.M.S. Heck. 1985. Localization of topoisomerase II in mitotic chromosomes. I. Cell Biol. 100: $1716-1725$.

Earnshaw, W.C., B. Halligan, C.A. Cooke, M.M.S. Heck, and L.F. Liu. 1985. Topoisomerase II is a structural component of mitotic chromosome scaffolds. J. Cell Biol. 100: 17061715.

Feinberg, A.P. and D.S. Coffey. 1982. The topology of DNA loops: A possible link between the nuclear matrix structure and nucleic acid function. In The nuclear envelope and the nuclear matrix. (ed. G.G. Maul), pp. 293-305. Alan R. Liss, Inc., New York.

Feinberg, A.P. and B. Vogelstein. 1983. A technique for radioactively labeling DNA restriction endonuclease fragments to high specific activity. Anal. Biochem. 132: 6-13.

Fey, E.G., G. Krochmalnik, and S. Penman. 1986. The nonchromatin substructures of the nucleus: The ribonucleoprotein (RNP)-containing and RNA-depleted matrices analyzed by sequential fractionation and resinless section electron microscopy. J. Cell Biol. 102: 1645-1665.

Flint, S.J. 1986. Regulation of adenovirus mRNA formation. Adv. Vir. Res. 31: 169-228.

Freimuth, P.I. and H.S. Ginsberg. 1986. Codon insertion mutants of the adenovirus terminal protein. Proc. Natl. Acad. Sci. 83: 7816-7820.

Gasser, S.M. and U.K. Laemmli. 1986a. Cohabitation of scaffold binding regions with upstream enhancer elements of three developmentally regulated genes of $D$. melanogaster. Cell 46: $521-530$.

Gasser, S.M. and U.K. Laemmli. 1986b. The organization of chromatin loops: Characterization of scaffold attachment site. $E M B O$ /. 5: 511-518.

Gasser, S.M., T. Laroche, J. Falquet, E. Boy de la Tour, and U.K. Laemmli. 1986. Metaphase chromosome structure. Involvement of topoisomerase II. J. Mol. Biol. 188: 613-629.

Graham, F.L., J. Smiley, W.C. Russell, and R. Nairu. 1977. Characteristics of human cell line transformed by DNA from human adenovirus type 5. J. Gen. Virol. 36: 59-72.

Groudine, M., M. Peretz, and H. Weintraub. 1981. Transcriptional regulation of hemoglobin switching in chicken embryos. Mol. Cell. Biol. 1: 281-288.

Hearing, P. and T. Shenk. 1985. Sequence-independent autoregulation of the adenovirus type 5 ElA transcription unit. Mol. Cell. Biol. 5: 3214-3221.

Hoeffler, W.K. and R.G. Roeder. 1985. Enhancement of RNA polymerase III transcription by the ElA gene product of adenovirus. Cell 41: 955-963.

Hofer, E. and J.E. Darnell. 1981. The primary transcription unit of the mouse $\beta$-globin gene. Cell 23: 585-593.

Hope, I.A. and K. Struhl. 1986. Functional dissection of a eukaryotic transcriptional activator protein, GCN4 of yeast. Cell 46: 885-894.

Jackson, D.A. and P.R. Cook. 1985. A general method for preparing chromatin containing intact DNA. EMBO I. 4: 913918.
Jones, N. and T. Shenk. 1979a. An adenovirus type 5 early gene function regulates expression of other early viral genes. Proc. Natl. Acad. Sci. 76: 3665-3669.

Jones, N. and T. Shenk. 1979b. Isolation of adenovirus type 5 host range deletion mutants defective for transformation of rat embryo cells. Cell 17: 683-689.

Kas, E. and L.A. Chasin. 1987. Anchorage of the Chinese hamster dihydrofolate reductase gene to the nuclear scaffold occurs in an intragenic region. J. Mol. Biol. 198: 677-692.

Kelly, T.J., Jr. 1984. Adenovirus replication. In The adenoviruses, (ed. H.S. Ginsberg), pp. 271-308. Plenum, New York.

Khitoo, G., L. Delorme, C.V. Dery, M.L. Tremblay, J.M. Weber, V. Bibor-Hardy, and R. Simard. 1986. Role of the nuclear matrix in adenovirus maturation. Virus Res. 5: 391-403.

Logan, J., S. Pilder, and T. Shenk. 1984. Functional analysis of adenovirus type 5 early region 1B. Cancer Cells 2: 527-532.

Ma, J. and M. Ptashne. 1987. Deletion analysis of GAL4 defines two transcriptional activating segments. Cell 48: 847-853.

McKnight, G.S. and R.D. Palmiter. 1979. Transcriptional regulation of the ovalbumin and conalbumin genes by steroid hormones in chick oviduct. J. Biol. Chem. 254: 9050-9058.

Melton, D.A., P.A. Krieg, M.R. Rebagliata, T. Maniatis, K. Zinn, and M.R. Green. 1984. Efficient in vitro synthesis of biologically active RNA and RNA hybridization probes from plasmids containing a bacteriophage SP6 promoter. Nucleic Acids Res. 12: 7035-7056.

Mermod, N., E.A. O'Neill, T.J. Kelly, and R. Tiian. 1989. The proline-rich transcriptional activator of CTF/NF-1 is distinct from the replication and DNA-binding domain. Cell 58: $741-753$.

Mirkovitch, J., M.-E. Mirault, and U.K. Laemmli. 1984. Organization of the higher-order chromatin loop: Specific DNA attachment sites on nuclear scaffold. Cell 39: 223-232.

Mitchell, P.J. and R. Tjian. 1989. Transcriptional regulation in mammalian cells by sequence-specific DNA binding proteins. Science 245: 371-378.

Morgan, G., H.S. Rosenkranz, and B. Medris. 1969. Structure and development of viruses as observed in the electron microscope. X. Entry and uncoating of adenovirus. I. Virol. 4: $777-784$.

Nelson, W.G., J. Pientak, E.R. Barrack, and D.S. Coffey. 1986 The role of the nuclear matrix in the organization and function of DNA. Annu. Rev. Biophys. Chem. 15: 457-475.

Pettit, S.C., M.S. Horwitz, and J.A. Engler. 1988. Adenovirus preterminal protein synthesized in COS cells from cloned DNA is active in DNA replication in vitro. I. Virol. 62: 496-500.

Phi-Van, L. and W.H. Strätling. 1988. The matrix attachment regions of the chicken lysozyme gene co-map with the boundaries of the chromatin domain. EMBO I. 7: 655-664.

Pienta, K.J. and D.S. Coffey. 1984. A structural analysis of the role of the nuclear matrix and DNA loops in the organization of the nucleus and chromosome. J. Cell Sci. Suppl. 1: $123-135$.

Pilder, S., M. Moore, J. Logan, and T. Shenk. 1986. The adenovirus E1B-55K transforming polypeptide modulates transport or cytoplasmic stabilization of viral and host cell mRNAs. Mol. Cell. Biol. 6: 470-476.

Rekosh, D.M.K., W.C. Russell, A.J.D. Bellet, and A.J. Robinson. 1977. Identification of a protein linked to the ends of adenovirus DNA. Cell 11: 283-295.

Robinson, A.J., H.B. Younghusband, and A.J.D. Bellett. 1973. A circular DNA-protein complex from adenoviruses. Virology 56: 54-69.

Schaack, J., P. Schedl, and T. Shenk. 1990. Topoisomerase I and 


\section{Schaack et al.}

II cleavage of adenovirus DNA in vivo: Both topoisomerase activities appear to be required for adenoviral DNA replication. J. Virol. 56: 78-85.

Small, D., B. Nelkin, and B. Vogelstein. 1985. The association of transcribed genes with the nuclear matrix of Drosophila cells during heat shock. Nucleic Acids Res. 13: 2413-2431.

Smart, J.E. and B.W. Stillman. 1982. Adenovirus terminal protein precursor: Partial amino acid sequence and the site of covalent linkage to virus DNA. I. Biol. Chem. 257: 1349913506.

Stief, A., D.M. Winter, W.H. Strätling, and A.E. Sippel. 1989. A nuclear DNA attachment element mediates elevated and position-independent gene activity. Nature 341: 343-345.

Stillman, B.W. 1983. The replication of adenovirus DNA with purified proteins. Cell 35: 7-9.

Stillman, B.W., J.B. Lewis, L.T. Chow, M.B. Mathews, and J.E. Smart. 1981. Identification of the gene and mRNA for the adenovirus terminal protein precursor. Cell 23: 497-508.

Thimmappaya, B., N. Jones, and T. Shenk. 1979. A mutation which alters initiation of transcription by RNA polymerase III on the Ad5 chromosome. Cell 16: 947-954.

Tremblay, L.M., C.V. Dery, B.G. Talbot, and J. Weber. 1983. In vitro cleavage specificity of the adenovirus type 2 proteinase. Biochim. Biophys. Acta 743: 239-245.

Verheijen, R., W. Van Venrooij, and F. Ramaekers. 1988. The nuclear matrix: Structure and composition. I. Cell Sci. 90: $11-36$.

Williams, J., B.D. Karger, Y.S. Ho, C.L. Castiglia, T. Mann, and S.J. Flint. 1986. The adenovirus E1B 495R protein plays a role in regulating the transport and stability of the viral late messages. Cancer Cells 4: 275-284.

Winberg, G. and T. Shenk. 1984. Dissection of overlapping functions within the adenovirus type $5 \mathrm{E} 1 \mathrm{~A}$ gene. $E M B O J$. 3: 1907-1912.

Yoshinaga, S., N. Dean, M. Han, and A.J. Berk. 1986. Adenovirus stimulation of tanscription by RNA polymerase III: Evidence for an E1A-dependent increase in transcription factor IIIC concentration. EMBO I. 5: 343-354.

Younghusband, H.B. and K. Maundrell. 1982. Adenovirus DNA is associated with the nuclear matrix of infected cells. $J$. Virol. 43: 705-713.

Zhai, Z.-H., X. Wang, and X.-Y. Qiani. 1988. Nuclear matrix-intermediate filament system and its alteration in adenovirus infected HeLa Cell. Cell Biol. Int. Rep. 12: 99-108.

Zhonge, Z., J.A. Nickerson, G. Krochmalnic, and S. Peman. 1987. Alterations in nuclear matrix structure after adenovirus infection. J. Virol. 61: 1007-1018. 


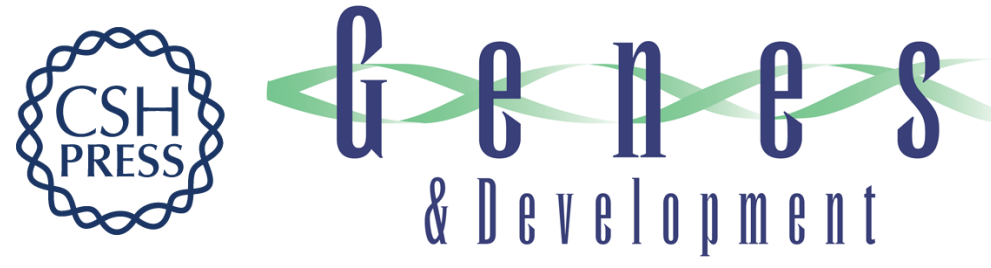

\section{Adenovirus terminal protein mediates both nuclear matrix association and efficient transcription of adenovirus DNA.}

J Schaack, W Y Ho, P Freimuth, et al.

Genes Dev. 1990, 4:

Access the most recent version at doi:10.1101/gad.4.7.1197

References This article cites 62 articles, 21 of which can be accessed free at: http://genesdev.cshlp.org/content/4/7/1197.full.html\#ref-list-1

License

Email Alerting

Service

Receive free email alerts when new articles cite this article - sign up in the box at the top right corner of the article or click here.

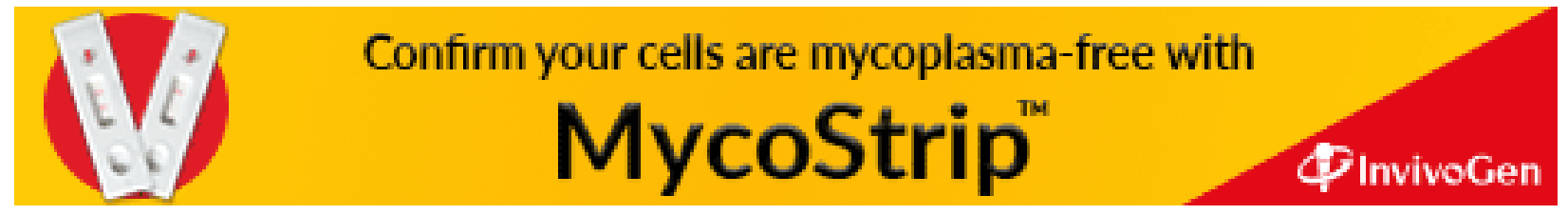

